volumes of Calvin's works printed in the 17th century. The Library also has Grotius' Opera Onnia.

The holdings in vernacular literary works by continental authors are scanty. I myself came across none in French or German. There is an interesting edition in Italian -- the Dialoghi del Sig. Speron Speroni, printed in Venice, 1596.

There are a few works useful for the history of science. They include some 16th-century editions of Euclid, Regnault 's Ia botanique mise a la portée de tout le monde (1574), Gravesande's Iatin Introduction to Newton (Leyden, 1721) and Newton's Chronology (printed the year after his death).

Miss Beatrice Saunders, the Iibrarian, will be glad to make Trinity's rare books available to those who want to use them. A phone call ahead of time would be appreciated, since most of these books have been placed for safekeeping in a locked room. Not all of these works are catalogued in Trinity's new catalogue.

N. Z. Davis.

The new Course in French Language and Literature is reserving one seminar hour each week for third year studerts to work on the 16 th century

\title{
NEW APPCTNTMENTS
}

Gwenda Echard, Dept. French, Atkinson College, 16th-cent. French humanism. Sister Geraldine, Ioretto Cillege, English Renaissance literature. Paul Grendler, Dept. History, ISth-cent. Italian intellectual history. David Kunzle, Dept. Fine Arts, Rensissance and Baroque art. J. M. R. Margeson, University College and Scarborough, Jacobean drama. John McClelland, Victoria, I6th-cent. French literature The Rev. T. M. McDonough, Irinity College, Theology, Luther. G. R. Sarolli, Dept. Italian Studies, Medieval literature, Machiavelli. Douglas Stewarc, Dept. Fine Arts, Barcque art. Timothy Suttor, St. Michael's, Reformation Theology and History. John Tobin, Dept. Englisin, Humsnities, York University, Miltor.

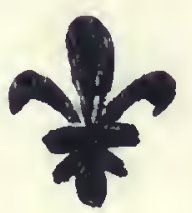

